\title{
Local Wisdom Values Assessment on NaikDango Ceremony: KanayatnDayaknese Society at Saham Village on Civic Culture of the people in Indonesia
}

\author{
PitalisMawardiBaging, MohdKhairulAmriKamarudin, MohdHanif Abdullah, \\ SurachateHakparn, KanitthaLertbunchardwong, TepvisitPotikengrith
}

\begin{abstract}
The association among culture and human are interrelated aspect in socio-cultural life. The beliefs of local wisdom NaikDango ceremony as civic at KanayatnDayaknese in Saham Village, SengahTemila District.This beliefs as divinity values between human and their relationship with God. The role of stakeholders to conserve and preserve the ceremony of NaikDango as the people culture, cultural resiliency depends on society interest or love for the surrounding culture. Respecting nature properly accordance with the principles of rituals. Family values should be retained in order to reinforce family harmony can be seen in Mutual Cooperation. The cultures that were passed on to the generations as cultural heritage of the indigenous people.The aim of this study to determine the beliefs of local wisdom and the value of divinity human relationship with God in NaikDango Ceremony. The study indicated that men communities, who always try to search for God and respect Him. The appreciation the surrounding environment, preserving it and make use of it with good ways.
\end{abstract}

Index Terms: Civic culture, KanayatnDayaknese society, local wisdom, NaikDango ceremony, Saham village.

\section{INTRODUCTION}

Deforestation or exploitation of forest areas for plantations, forest fires and the draining of peatlands are the main causes of emissions in Indonesia. Similarly, the deforestation rate reaches 2 million hectares and this condition places Indonesia as the first country recorded as the highest deforestation deterioration in the world [1], [2]. The forests of West Kalimantan are already visibly transformed, which was once green by large trees now green by the dominating palm oil plantations. Community-based forest management and conservation is only a matter of sustainable and sustained local wisdom to address climate change and the global crisis [3]-[5].

In the theory of environmental ethics, anthropocentrism views man as the centre of the system of the universe.

Revised Manuscript Received on September 14, 2019.

Pitalis Mawardi Baging, Geography Study Program IKIP PGRI Pontianak, Indonesia and East Coast Environmental Research Institute (ESERI), Universiti Sultan ZainalAbidin, Gong Badak Campus, 21300 Terengganu, Malaysia.

Mohd Khairul Amri Kamarudin, Faculty of Applied Social Science (FSSG) and East Coast Environmental Research Institute (ESERI), Universiti Sultan ZainalAbidin, Gong Badak Campus, 21300 Terengganu, Malaysia.

Mohd Hanif Abdullah, East Coast Environmental Research Institute (ESERI), Universiti Sultan ZainalAbidin, Gong Badak Campus, 21300 Terengganu, Malaysia.

Surachate Hakparn, Tourist Police Bureau, Bangkok, Thailand.

Kanittha Lertbunchardwong, Faculty of Social Sciences and Humanities, Mahidol University, Nakhon Pathom, Bangkok, Thailand.

Tepvisit Potikengrith, Special Branch Police Bureau, Bangkok, Thailand.
Humans and their interests are considered the most decisive in the ecosystem order and its relation to nature [6], [7]. To return to the balance of human life, the way out according to perenealism is to return to the values (back to value) that underlies human life at first [8].

Apart from that, the enhancement in technology leads to cultural connections which are influence to the occurrence of an essential change. The development of globalization of culture will encourage in daily life arrangements of human life. Hereby, the cultural heritage of the indigenous people is the developing of cultures that were handed on to the generations in definite society [9]. The improvement of info ultimately led to the harmful impact of the culture among societies especially among younger generation [10].

Every ethnic community in Indonesia has a body of tradition comprising social norns, law, rituals and ceremonies, and religion, called adat. Adatis unique to each ethnic community and is an important component of group identity. Every Dayak subculture has its own adat, which often differs from village to village. As will be explained later in much greater detail, adatcomprises norms, custorns, and regulations regarding just about every aspect of life. Integral to the Dayak worldview, and practically seamlessly incorporated into adatis the conviction that there is more to reality than meets the eye. Traditionally the Dayaks have been, and the majority still are, animists, believing that most events are caused in one way or another by any of a myriad of spiritual forces. The adatheld in common by the various sub-cultures that have come to be called Dayak, and interwoven through and through with animistic beliefs, is intrinsic to their cultural and ethnic identity.

GawaiDayak ritual cannot be separated from the culture in which people's lives Dayak. Unique culture pattern and mysticism is very thick and feels when following this ritual. The style culture that is friendly to nature, characteristic singing, dance, until the spell is always there when the ritual is performed. The existence of this ritual can push the preservation of Dayak culture which describes the way of life of the Dayak people are famous for the observance of their customs. This was confirmed by the opinion [11].

GawaiDayakcan be viewed from two perspectives, namely the cultural and literary perspectives. Can be seen from the culture perspective because the GawaiDayak ritual describes the habits, lifestyle of Dayaks people in general is 


\section{LOCAL WISDOM VALUES ASSESSMENT ON NAIK DANGO CEREMONY: KANAYATN DAYAKNESE SOCIETY AT SAHAM VILLAGE ON CIVIC CULTURE OF THE PEOPLE IN INDONESIA}

still traditional. Can be seen also from the literature perspective because GawaiDayak ritual is presents the activity in the form of traditional art performances that only can be seen when the ritual performance to the public. The core activities in the GawaiDayak ritual are Nyangahatn activities. Nyangahatn is ceremonies to appeal to Jubata for the ceremonies of GawaiDayak / NaikDango ritual are run smoothly. According to [11], Nyangahatn is one of the form of nonstory oral literature in DayakKanayatn. This was confirmed by [12].

In the process, there is traditional knowledge, solidarity, togetherness, spirituality, local wisdom and anticipatory attitude. Through this hereditary activity, the knowledge and practice of local wisdom of hereditary heritage still color the way of life of farming done an Indigenous Dayak community. Dayak Indigenous People in Kalimantan, especially in West Kalimantan since the early ancestors of the Dayak community have been struggling with the opening of paddy fields for sustainability through cultivation. The activities of farming are generally done jointly involving both women and men and children. The practice of farming is also marked by a number of rituals as an expression of gratitude, thanks, thanks to salvation and fortune. Farming activity is a business practice on the management of surroundingnatural resources that are done down descend

\section{METHODOLOGY}

The data was gathered by statement from Saham Village, SengahTemila district, Landak regency using the qualitative structure. Tools of the study was using interview session from the respondents. The respondents comes from various background which were academicians that were experts in Dayaknese cultures, the Head of the village, Local Custom Figures (the elders in Kanayatn tribes), Religious Leaders, Temenggung (chief). To attain comprehensive data, the researcher requested each member to give insights and information regarding the culture and some of the source of the reference for the story, and this progression continue by using snowball methods. This method was chosen in order to acquire full information of primary data of respondents.

\section{RESULTS AND DISCUSSION}

\section{A. The Origin of NaikDango}

GawaiDayakritual is one of the rituals performed during the rice harvest season ends. Implementation of this ritual is routinely held every year on May 20th. In some places, GawaiDayakritual has a different name, NaikDangois a term that exist in DayakKanayatn, MakanTahunterm used by the KanayatnDayak community around the Sarawak which most have converted to be Islam [13]. The ritual natures are expression the gratitude to God of agricultural until the next year. In the region of Sabah-Malaysia, DayakKanayatn (Kadazan) named this ritual as TadauKeamatan. Aside being a gratitude expression, the ritual implementation are also to honor the mythical visit of fertility god, accompanied by prays and offerings in order to get back a bountiful harvest for the best year and get protection.

In a Nyangahatnritual there is ritual chanting in the form of spell/mantra. Pray offered to Jubataas a tool intended to apply for a permit this perform rituals, invoke protection to avoid the plague. Spells can only be pronounced by Panyagahatn, i.e. someone who knows the ins and outs of customs. The spells recited solemnly and with a rhythm that seemed constant and regular. After the Nyangahtnritual completed, some traditional dance performances showcased. Each dance performance contains movement that symbolize communication with Jubata. These then led to the implementation of these dances are magical and sacred. One of the dances is performed when the GawaiDayakritual dance is Jonggan. This dance was performed as an expression of gratitude to Jubata. One of the parts contained in Jonggandance is poetry; sung like pantun/traditional poetry. Poetry in jonggandance is in the form of traditional poetic consisting of four lines rhyming two-two, which is patterned of $a-a-a-a, a-b-a-b$, and $a-a-b-b$. Each line consists of four words. All of Jonggan poetry is consisting of two parts, namely sampiranand content. Sampiranare the first two lines, which are often related figures of speech and the last two lines are the contents of the poetry [11].

There are also forms of dance in the implementation of this ritual. The dance focuses on the various movements of all limbs. This means that the dance movements involved non-verbal communication. Every movement is following the music. Each of these movements has emphasis and repetition on the particular movement. This happens because every movement, emphasis and repetition has a specific purpose and meaning. Similarly, in the literature that requires carefulness observation on figures' gesture if to be understood their character, that is, even the emotions were experienced by the figures in the fictional works.

B. Values of Local Wisdom in NaikDango Ceremony as Civic Culture in KanayatnDayaknese Community

NaikDango ceremony can be assumed through spiritual ways. NaikDango ceremonial comprises a lot of mysteries which is cannot be understanding by the people in any rational ways. Therefore, this ceremony can be seen at ceremony procession as panyangahan (purifying) period and beforehand the feast begins called disangahan (purified), this action was completed to ask for blessing from the gods).

Adat as manipulation raises some implications regarding the nature of morality. The rightness or wrongness of an action is determined by whether the action achieves the desired result. Prescribed actions are to be avoided because they might being calamity or ill fortune to the individual or the community. A proscribed action might not be morally wrong if one is able to 'pay the adat' to smooth over the potential disruption in the overall harmony before the individual or community suffers the consequences from the angered ancestral or other spirits. The third component of adatis the element of uncertainty and anxiety from never king able to know exactly what the spirits or gods want or demand and never king certain that their demands have been met or their desires satisfied. Great attention is given to the

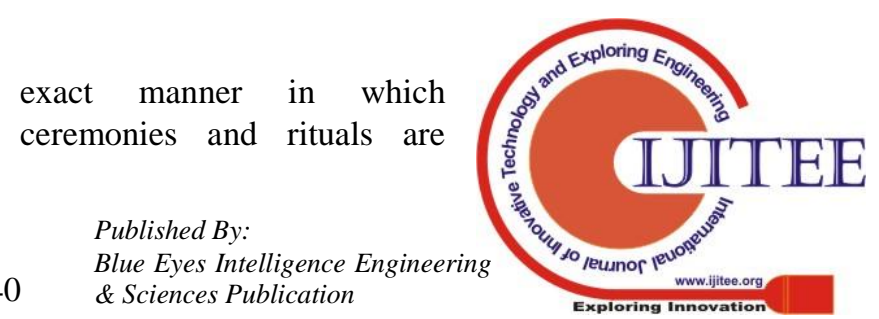


carried out, for it is only if everything is performed exactly as required that the spirits or forces are likely to be satisfied and cooperate with humans. The values of these symbols in NaikDango ceremony are as follows:

1) Tumpi (sticky cakes) represents the spirit of unity among citizens.

2) Boiled eggs imply the unity and hard to be divided so that it can be used to cast-off all threats from within and from outside.

3) Unity and brotherhood were represents by sticky rice because when it was cooked, the rice will become sticky and difficult to be disjointed.

4) Swine represents the customary laws that should be executed in the society.

5) Shell powder that is white which is comes from shells or limestone, symbolizes cleanliness and hospitality

6) Colour of the Gambir (sour plant) leaves which is yellowish represents tenacity and patience in achieving targets and it taste bitter and it implies firmness.

7) Pinang is centered on the nature of palm fruit, which grows straight and has a bunch of fruits.

8) Gong indicates of loud voice which is disturb statement among people.

9) Jaduh (rice storage) is the ingredients for loading rice. It symbolizes the human hard work to grow rice.

10) Beliukng (cutting tools), a cutting tool that is normally used the balance thing in offering.

11) Rice signifies the supplement for customary laws of families and to refresh the environment.

C. The Role of Academics in Preserving the Local Wisdom Values as Civic Cultures in NaikDango Ceremony in KanayatnDayaknese Community

Apart from the local people, education experts also have role by picking of this ceremony as additional school subject at school (MuatanLokal). The whole society and the aboriginal leaders play an imperative part in conserving NaikDango ceremony, exclusively about the sacred values which be duty-bound to be kept by the people. Apart from that most people from in Saham Village, SengahTemila District, give responds that they did not perform NaikDango ceremony because they did not own any of farm or rice field that not encourage them to participate in the ceremony.

The education is one of the actual mechanisms to introduce the local cultures of the citizen identity. The role of education in retaining and introducing local cultures among communities. The curriculum on extra subjects and they made necessary school subjects by the government. The government elements, Temenggung, and academics, the main points were as follows:

- Through the method of explaining to the younger generation by a few activities carried out during ceremony such as the craft arts and the art of playing.

- The sanctity of the ritual without omitting or adding the elements of the ceremony to develop the people understanding of sacred ceremonial during the ceremony to honor Jubata.

- The implementing these values into additional subjects at school. There are lesson materials used such as the musical instruments, folk songs, traditional dresses during NaikDango ceremony.
- The emphasis the things which are considered important such as ponompo dance (ngantardango rice), nyangahan (people entrusted to say the prayer) and to introduce local culture to the people around.

\section{Factors That Influence the Development of Local} Wisdom Values in NaikDango Ceremony

In this farming activity with shifting cultivation, the Dayak tribe in utilizing the forest as a field area is not done as they please, there are a number of rules that must be obeyed, it is intended to keep the forests that are part of their lives sustained. In forest management basically, Dayak people always derived from the religious system. The essence contained in the religious system is to guide and emulate the Dayak community to always behave in harmony with the dynamics of the universe, so as to manifest the balance of the relationship between man and the natural environment. As for the values of local wisdom contained in the tradition of shift in cultivation (BaumaTahutn) is among others. The local wisdom values in NaikDango ceremony as civic culture on KanayatnDayaknese community but these values have become less popular because most of the people are revolving from farming to palm.

The internal factors involving the influence the wisdom such as the disappearing role of village elders, the younger generation perception about local culture. The influence of television and bands also considered as one of the main factor that discourage the ritual ceremony. The external influence initiated the importance towards local cultures changes and currently people recognize more about foreign cultures compares to local ones. The influence of various religious knowledge make the people have undesirable opinion to this culture (NaikDango), specifically the thanksgiving ritual that are perceived as conflicting to their current faiths.

There are results of interviews showed among respondents from the communities of leaders, traditional leaders and Temengung about the problems affecting the underdevelopment of the values of local wisdom in NaikDango ceremony. The factors affecting the growth of NaikDango ceremony in the society are generally influenced by two factors, internal and external. Other influence is that many people do not actually have faith in supernatural things. In addition, some people alleged it as fanaticism which contradicts with their religious views.

\section{CONCLUSION}

The beliefs of NaikDango ceremony comprise family common, religious and solidarity values. These values are associated to each other which are enclosed in the values of Pancasila. The conservation of NaikDango values is very significant role because it is cultural uniqueness cultural in Indonesia. The aspects affecting of ceremony including changes in the environment, culture considers to the values of religious, cultural transition and changes in population

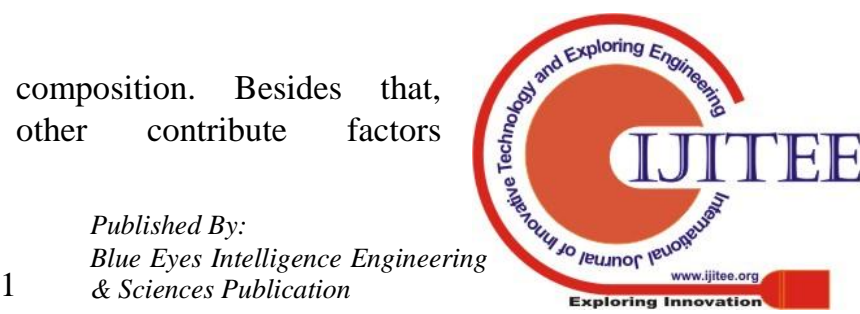




\section{LOCAL WISDOM VALUES ASSESSMENT ON NAIK DANGO CEREMONY: KANAYATN DAYAKNESE SOCIETY AT SAHAM VILLAGE ON CIVIC CULTURE OF THE PEOPLE IN INDONESIA}

namely technology, education, and religion.

\section{ACKNOWLEDGMENT}

The author would like to thank KPM for providing financial support for this research on the (UniSZA/2017/SRGS/17) - R0019-R017, (RAGS/ 1/2015 /WAB05/ UNISZA / 02/1) and (FRGS/1/2017/WAB05/UNISZA/01/ 1) - RR222. Special thanks are also dedicated to Universiti Sultan ZainalAbidin (UniSZa) and Geography Study Program IKIP PGRI Pontianak, Indonesia.

\section{REFERENCES}

1 P. K. Gellert, "The shifting natures of "development": Growth, crisis, and recovery in Indonesia's forests," World Development, 33(8), 2005, pp. 1345-1364.

2 M. K. A. Kamarudin, M. E. Toriman, M. H. Rosli, H. Juahir, N. A. Aziz, A. Azid, S. F. Zainuddin, and W. N. Sulaiman, "Analysis of meander evolution studies on effect from land use and climate change at the upstream reach of the Pahang River, Malaysia," Mitigation and Adaptation Strategies for Global Change, 20(8), 2015, pp. 1319-1334.

3 M. K. A. Kamarudin, N. A Wahab, H. Juahir, N. M. Wan, M. E. Toriman, F. M. Ata, A. Ghazali, A. Anuar, H. Abdullah, N. I. Hussain, and S. H. Azmee, "The potential impacts of anthropogenic and climate changes factors on surface water ecosystem deterioration at Kenyir Lake, Malaysia," International Journal of Engineering and Technology (UAE), 7(3.14), 2018, pp. 67-74.

4 M. K. A. Kamarudin, N. A. Wahab, A. F. Mamat, H. Juahir, M. E. Toriman, N. F. Wan, F. M. Ata, A. Ghazali, A. Anuar, and M. H. M. Saad, "Evaluation of annual sediment load production in Kenyir Lake reservoir, Malaysia," International Journal of Engineering and Technology (UAE), 7(3.14), 2018, pp. 55-60.

5 M. K. A. Kamarudin, N. A. Wahab, A. F. Mamat, H. Juahir, M. E. Toriman, N. F. Wan, F. M. Ata, A. Ghazali, A. Anuar, and M. H. M. Saad, "Evaluation of annual sediment load production in Kenyir Lake reservoir, Malaysia," International Journal of Engineering and Technology (UAE), 7(3.14), 2018, pp. 55-60.

6 A.S. Keraf, Etika Lingkungan Hidup. Jakarta: Penerbit Buku Kompas, 2010.

7 M. K. A. Kamarudin, M. E. Toriman, M. Sharifah, I. Mushrifah, N. R. Jamil, and M. B. Gasim, "Temporal variability on lowland river sediment properties and yield," American Journal of Environmental Sciences, 5(5), 2009, pp. 657-663.

8 S. Bahri, N. Supriatna, H. Sjamsuddin, and E. Wiyanarti, "The shifting cultivation of Bauma Tahutn tradition in the Dayak Kanayatn people in West Kalimantan," International Conference on Science and Education and Technology, 2018, pp. 423-430.

9 F. Cameron, and S. Kenderdine, Theorizing Digital Cultural Heritage: A Critical Discourse. London: MIT Press, 2007.

10 W. W. Gaver, A. Boucher, S. Pennington, and B. Walker, "Cultural probes and the value of uncertainty," Interactions, 11(5), 2004, pp. 53-56.

11 H. Herlina, A. Andayani, H. J. Waluyo, and B. Setiawan, "Perspective literature in ritual Gawai Dayak literature teaching materials as regional college," International Conference on Teacher Training and Education, 2016, pp. 512-516.

12 U. D. Oktaviani, "Mantra upacara Ngabati'pada upacara pertanian suku Dayak Kanayatn di Dusun Pakbuis Desa
Banying Kecamatan Sengah Temila Kabupaten Landak Kalimantan Barat," Vox. Edukasi: Jurnal Ilmiah Ilmu Pendidikan, 6(2), 2015, pp. 168-183.

13 M. M. Magiman, and O. Yatim, "Simbol dalam makan tahun masyarakat Kadayan, Sarawak," Jurnal Melayu, 9, 2012, pp. 259-287.

\section{AUTHORS PROFILE}

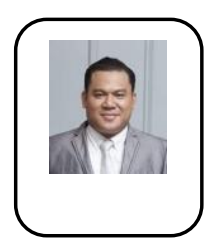

PitalisMawardiBagingisa lecturer in Geography Study Program IKIP PGRI Pontianak, Indonesia and $\mathrm{PhD}$ student in East Coast Environmental Research Institute (ESERI), Universiti Sultan Zainal Abidin. His research interest include Environmental management, Society and culture study.

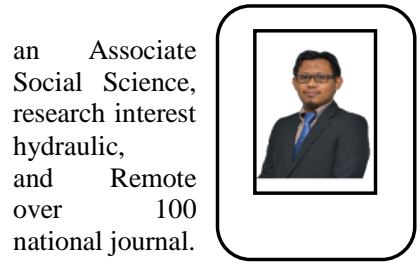

MohdKhairulAmriKamarudinis Professor in Faculty of Applied Universiti Sultan ZainalAbidin. His includes hydrodynamic and environmental management, GIS Sensing (RS). He has published publications in international and

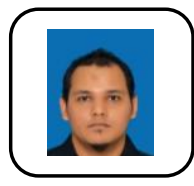

MohdHanif Abdullahis currently served as Research Assistant in the East Coast Environmental Research Institute (ESERI), Universiti Sultan Zainal Abidin. His research interest include environmental management and environmental science.

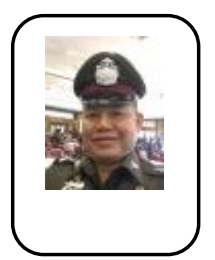

TepvisitPotikengrithis anPolice officer in Specia Branch Police Bureau, Bangkok, Thailand and PhD student in Thailand university. His research interest include criminology, communication, environment, community, engagement and law. 